\title{
Nutritive value and aversion of honey mesquite leaves to sheep
}

\author{
R. BAPTISTA AND K.L. LAUNCHBAUGH
}

At the time of research, authors were graduate research assistant and assistant professor in the Range, Wildlife and Fisheries Management Department, Texas Tech University, Lubbock, Tex 79409-2125. Currently, authors are Altiplano Regional Coordinator for the Programa Campesino Alternativo de Desarrollo (Alternative Development Peasant Program), La Paz, Bolivia and assistant professor of Rangeland Ecology and Management Department, University of Idaho, Moscow, Ida 83844-1135, respectively.

\begin{abstract}
Honey mesquite (Prosopis glandulosa Torr.) is an invasive native plant that is abundant in Mexico and the Southwestern United States. We initiated 2 studies to determine if: 1) mesquite could provide valuable forage for domestic herbivores; and 2) if mesquite causes conditioned flavor aversions in ruminants. An in vivo digestion trial was completed with 15 lambs assigned to diets of $0,5,10,15$, or $20 \%$ dried mesquite leaves mixed with alfalfa hay to measure effects of mesquite on intake and digestion. Proportions of mesquite leaves $>5 \%$ of the diet negatively affected dry matter (DM) intake, nitrogen $(\mathrm{N})$ balance, energy balance and weight gain. Mesquite intake was highest at the $5 \%$ level averaging $1.81 \mathrm{~g} \mathrm{~kg}^{-1}$ body weight (BW), mesquite intake of the other mesquite-containing diets averaged $0.78 \mathrm{~g} \mathrm{~kg}^{-1} \mathrm{BW}$. Apparent digestibility was not affected by the level of mesquite in the diet. An in situ digestion trial did however, reveal that pure alfalfa was more digestible than mesquite leaves. A conditioned flavor aversion (CFA) trial tested the effect of post-ingestive feedback from mesquite on the intake of a novel food (rye). Lambs were offered rye and then ground mesquite was infused into their rumens by esophageal tube. Twenty one lambs were assigned to 3 dosing treatments: 0 (control), 3.0 (low), or 4.5 (high) $g$ of mesquite per $\mathrm{kg} \mathrm{BW}$. Two days after dosing, lambs that received mesquite infusions ate less rye than controls indicating the formation of a CFA. The aversion to rye persisted for at least 2 days. The high dose of mesquite also decreased intake of the alfalfa basal ration for at least 3 days and resulted in persistent diarrhea in lambs. Chemical analysis of mesquite leaves revealed similar nutritive quality (crude protein, gross energy, and fiber) as mature alfalfa. However, to exploit the forage value of mesquite, the allelochemicals that cause flavor aversions and other negative digestive consequences need to be identified and overcome.
\end{abstract}

Key Words: browse, conditioned aversion, digestion trial, forage value, Prosopis glandulosa, secondary compounds

Mesquite species (Prosopis spp.) cover approximately 34 million hectares of rangeland in the southwestern United States (Dahl 1982), and are among the most predominant invasive

Research was funded by College of Agricultural Sciences and Natural Resources at Texas Tech University and the World Bank Bolivia Project.

Authors wish to thank Drs. Emilio Laca and Rodney Preston for invaluable advice on design of the digestion and aversion experiments.

Manuscript accepted 24 Apr. 2000.

\section{Resúmen}

El mesquite dulce (Prosopis glandulosa Torr.) es una planta invasora nativa, abundante en Mexico y en el suroeste de los Estados Unidos. Se realizaron 2 estudios para determinar si el mesquite: 1) puede proveer valor forrajero para herbivoros domesticos; y 2) si provoca aversiones condicionadas en rumiantes. Se realizó un ensayo de digestión in vivo con quince corderos alimentados con dietas conteniendo $0,5,10$, o $20 \%$ de hojas secas de mesquite mezcladas con heno de alfalfa para medir los efectos del mesquite sobre algunos parámetros digestivos. Proporciones de hoja de mesqutie en la dieta superiores al $5 \%$ afectaron negativamente el consumo de materia seca, el balance de nitrógeno, el balance de energia y las ganancias de peso. El consumo de mesquite fué más alto al nivel del $5 \%$, promediando $1.81 \mathrm{~g} \mathrm{~kg}^{-1}$ de peso vivo. El consumo de mesquite en las otras dietas promedio $0.78 \mathrm{~g} \mathrm{~kg}^{-1}$ de peso vivo. La digestibilidad aparente de la materia seca no se vio afectada por el nivel de mesquite en la dieta. Sin embargo, un ensayo de digestión in situ reveló que la alfalfa fué mas digestible que las hojas de mesquite. El experimento de aversión condicionada (AC) determinó el efecto de las consecuencias post-ingestivas del mesquite sobre el consumo de un alimento no familiar (centeno). Los corderos recibieron una oferta de centeno y a continuación infunsiones de mesquite molido en sus rumenes mediante el uso de un tubo esofágico. Veintiún corderos fueron asignados a las siguientes dosis de mesquite: 0 (control), 3.0 (dosis baja), y 4.5 (dosis alta) $\mathrm{g}$ de mesquite por kg de peso vivo. Dos dias después de aplicar las dosis, los corderos que recibieron infusiones de mesquite consumieron menos centeno que los controles, indicando la formación de una AC. La aversión al centeno persistió por al menos 2 dias. La dosis alta de mesquite también disminuyó el consumo de la dieta basal de alfalfa por al menos 3 dias y provocó diarrea persistente en los corderos. Los análisis quimicos de las hojas de mesquite revelaron una calidad nutricional (proteina cruda, energia bruta, y fibra) similar a la de la alfalfa. Sin embargo, para aprovechar el valor forrajero de mesquite, es necesario identificar y anular los compuestos químicos que causan aversiones y otras consecuencias digestivas negativas.

plants of this region. Mesquite competes for water, light, and nutrients with desirable forage species (Meyer et al. 1971). Honey mesquite (Prosopis glandulosa Torr.) is the most common species of mesquite in Texas, infesting about 23 million hectares (Fisher 1977). Fifty years of efforts to control mesquite by mechanical, chemical, and pyric means have not significantly 
slowed expansion nor reduced density of mesquite except in small intensively managed areas (Dahl and Sosebee 1984). As mesquite control becomes increasingly expensive (Holechek and Hess 1994), it is important to consider potential uses and benefits of mesquite.

As a forage, mesquite beans have long been recognized as an important energy source for humans and animals (Meyer et al. 1971, Zolfaghari et al. 1982). Mesquite leaves, however, are considered unpalatable and of low forage value (Lyon et al. 1988). The reason for this low forage value is unclear because mesquite leaves contain levels of crude protein and fiber similar to mature alfalfa (Unpublished data, Launchbaugh and Laca). Mesquite leaves do, however, contain flavanoids (Solbrig et al. 1977), alkaloids and nonprotein amino acids (Cates and Rhoades 1977) that may act as feeding deterrents or toxicants. The forage value of mesquite leaves could be improved if reasons for low palatability and toxicity could be identified and overcome. Mesquite stems have thorns that may also limit browsing. However, it is apparent that they are not the primary limiting factor because spines do not prevent the consumption of mesquite beans.

To understand why herbivores do not readily eat mesquite leaves and to assess their nutritional value for ruminants, we measured the voluntary intake and digestibility of mesquite leaves by sheep. Our initial objective for this research was to determine the effect of mesquite leaves in mixed alfalfa diets on dry matter intake, apparent digestibility, nitrogen retention, and energy digestibility by sheep. Our first set of experiments revealed a profound effect of mesquite content on the intake of mesquite-containing diets. To determine why mesquite influences voluntary intake we conducted a feeding trial to see if mesquite ingestion causes aversive feedback resulting in conditioned aversions. Conditioned aversions have been observed for many plants and have been hypothesized as the major mechanism by which herbivores learn to avoid plants that contain allelochemicals (Provenza et al. 1992).

\section{Materials and Methods ${ }^{1}$}

Research was conducted with domestic sheep at the Texas Tech University agricultural research facility near New Deal,

\footnotetext{
${ }^{1}$ Research protocol was approved by the Texas Tech University Animal Care and Use Committee (Protocol\# 95463).
}

Tex. $\left(33^{\circ} 43^{\prime} \mathrm{N}, 101^{\circ} 50^{\prime} \mathrm{W}\right)$. All experiments were conducted with honey mesquite leaves collected at the Texas Tech Experimental Ranch near Justiceburg, Tex. (33 $\left.02^{\prime} \mathrm{N}, 101^{\circ} 12^{\prime} \mathrm{W}\right)$. Sheep were selected for this research because the research was designed to improve livestock grazing practices on Texas rangeland. We studied sheep, instead of cattle, because they eat much less, making the research more feasible, and digestion parameters elucidated with sheep are generally applicable to cattle (Van Dyne and Weir 1964, Harris et al. 1967)

\section{In Vivo Digestion Trial}

In vivo digestibility was determined for mixed diets of alfalfa hay and mesquite leaves. Five diets were prepared with 0,5 , 10,15 , and $20 \%$ mesquite mixed with alfalfa hay on an as-fed basis. The highest level was set at $20 \%$ because a preliminary experiment showed very limited intake of diets containing more than $20 \%$ mesquite. A low quality alfalfa hay was selected for this study because it has similar nitrogen (N) and fiber content as mesquite leaves (Unpublished data, Launchbaugh and Laca). Diets were prepared with dried mesquite leaves, rather than fresh, because results of a preliminary experiment showed no difference in intake between fresh and dried leaves, indicating allelochemicals in mesquite are not volatilized when dried. In preliminary experiments, 18 lambs were fed diets of either fresh or dried chopped mesquite leaves at 10, 30, or $50 \%$ of an alfalfa hay ration for 10 days. A summary of the last 5 days of the trial revealed that intake of diets containing $10 \%$ mesquite was more than intake of diets with $50 \%$ mesquite leaves (12.3 and $4.4 \mathrm{~g} \mathrm{~kg}^{-1}$ body weight, respectively). Overall, intake of diets containing dry mesquite leaves was similar to diets with fresh mesquite leaves (8.1 and $9.1 \mathrm{~g} \mathrm{~kg}^{-1}$, respectively). Dried leaves allowed for easier storage and handling.

Mesquite leaves were collected by hand plucked during 2 weeks in September and October of 1995 and oven dried at $45^{\circ}$ $50^{\circ} \mathrm{C}$ for 5-7 days then stored in a dry unheated building. Leaves were dried at $<$ $50^{\circ} \mathrm{C}$ to maintain moderate levels of fermentable carbohydrates without reducing digestibility through the Malliard or other complexing reaction (Wolf and Carson 1973, Deinum and Maassen 1994). Both mesquite and alfalfa hay were ground with a hammer mill (12.7 $\mathrm{mm}$ screen) to reduce sorting of mixed diets when fed.

Digestion Trial. Fifteen fine-wool wether lambs (8-9 months old) were used in a digestion trial consisting of a 5-day pre-trial feeding period, 5-day acclimation period, and 7-day collection period. Animals were weighed (after fasting 12 hours) before the acclimation period and after the collection period. The average initial weight of lambs was $28.1 \mathrm{~kg} \pm 2.6$ SE. Lambs were randomly assigned to 1 of 5 diets (3 lambs per diet): 0, 5, 10, 15, or $20 \%$ dried mesquite leaves mixed with alfalfa hay, as fed. In the pre-trial feeding period, each lamb was placed in an individual $1.5 \times 2 \mathrm{~m}$ wire pen and given ad libitum access to food twice daily (0800 and 1800 hours). Uneaten food, generally less than $200 \mathrm{~g}$, was removed and replaced with a freshly prepared ration at each feeding. We did not estimate the proportion of mesquite in orts to determine the extent of sorting by lambs. Orts were of similar crude protein and gross energy content as the diet, and visual inspection revealed little evidence of sorting. Lambs were placed in metabolism crates $(0.75 \times 1.5 \mathrm{~m}) 5$ days before the experimental collection period to allow acclimation to the crates. Metabolism crates had wire mesh floors through which dung fell onto a screen collection tray. Urine passed through the dung screen tray and was deposited in a metal pan that was angled so that urine was collected in 2-gallon plastic buckets. Feeding during the acclimation period was as pre-trial feeding. During the 7-day collection period, treatment diets were offered twice daily (0800 and 1800 hours) and dung and urine were collected each day (1700 hours).

Dung was weighed by individual and a $20 \%$ aliquot was pooled with other daily samples of that individual and frozen. At the end of the trial, the total dung sample from each animal was thawed and mixed thoroughly and a $400 \mathrm{~g}$ subsample was taken. Subsamples were dried at $55^{\circ} \mathrm{C}$ and ground to pass through a $1 \mathrm{~mm}$ screen for subsequent chemical analysis. Dung was analyzed for nitrogen $(\mathrm{N})$ and gross energy (GE) content using macro Kjeldahl (AOAC 1984) and bomb calorimetry procedures (Harris 1970), respectively.

Total urine output was measured for each animal and a $10 \%$ aliquot (by volume) was collected daily, composited, and refrigerated. To each urine collection container, $200 \mathrm{ml}$ of $0.1 \mathrm{~N} \mathrm{HCL}$ was added to prevent volatilization of ammonia (Schneider and Flatt 1975). At the end of the collection period, a subsample (400 $\mathrm{ml}$ ) of each pooled urine sample was collected and frozen for chemical analysis. Analysis of urine included $\mathrm{N}$ by macro 
Kjeldahl (AOAC 1984) and GE by bomb calorimetry (Harris 1970). For bomb calorimetery, urine samples $(100 \mathrm{ml})$ were filtered into glass beakers, frozen, then freeze dried; the residue was weighed and made into pellets. Urine pellets, weighing 0.3 to $0.5 \mathrm{~g}$, were stored in a freezer to ensure dryness for bomb calorimetry (Paladines et al. 1963). Urine samples were weighed before and after freeze drying to determine dry matter content.

Composition of Experimental Diets. Diets were analyzed for $\mathrm{N}$ by Kjeldahl techniques (AOAC 1984) and GE by bomb calorimetry (Harris 1970). Neutral detergent fiber (NDF) and acid detergent fiber (ADF) were determined following the filter bag technique (Komarek et al. 1994), which is a modification of the conventional Van Soest fiber analysis (Van Soest et al. 1991).

Four rumen cannulated fine-wool wethers (1 year old) were used to determine in situ dry matter (DM) digestibility of experimental diets (Harris 1970). Wethers were fed an alfalfa hay basal ration containing 5\% mesquite for 15 days before the experiment. Six levels of mesquite $(0,5,10,15,20$, and $100 \%)$ were mixed with alfalfa hay. Mesquite and alfalfa samples were ground separately in a Wiley mill to pass a $2-\mathrm{mm}$ screen. Twelve dacron bags $\left(50 \mathrm{~cm}^{2}, 60 \mu\right.$ mesh $)$ were prepared for each sheep (2 bags/treatment). Alfalfa-mesquite samples were weighed to $1 \mathrm{~g}$ and placed in bags. Two glass marbles were also placed in each bag to ensure bag immersion into rumen fluid. Each bag was closed by tightly tying with nylon fishing line and then dried overnight at $60^{\circ} \mathrm{C}$ to obtain the initial weight. The in situ bags were soaked in cool tap water for about 15 minutes and then inserted in the rumen-fistulated sheep for 48 hours. After rumen fermentation, the bags were removed and rinsed with tap water until water ran clear, then oven dried at $60^{\circ} \mathrm{C}$ for 24 hours and weighed to obtain final undigested DM. In situ DM digestibility was defined as the weight of sample lost during fermentation expressed as a percentage of initial sample weight.

Data Summary and Experimental Design. Based on chemical analysis of feed, orts, dung and urine, we calculated the DM digestibility, $\mathrm{N}$ balance (consisting of $\mathrm{N}$ intake, $\mathrm{N}$ output, and retained $\mathrm{N}$ ), GE intake, GE output, and Digestible Energy (DE) for lambs on various alfalfamesquite diets by equations presented by Pritz et al. (1997). The in vivo digestion trial was analyzed as a completely randomized analysis of variance (ANOVA) with DM intake as a covariate. SYSTAT for Windows (1992) and SAS (1996) statistical packages were used for analysis. Logarithmic or fractal transformations were conducted on data that did not follow a normal distribution or did not have homogenous variances (Steel and Torrie 1980). Mean separation was performed using Fisher protected LSD procedure with a $0.05 \alpha$-level. Orthogonal comparisons were conducted to examine linear, quadratic, and cubic relationships between intake variables and proportion of mesquite in the diet (Steel and Torrie 1980).

\section{Conditioned Flavor Aversion Trial}

When an animal eats a new food and experiences gastro-intestinal malaise it forms a dislike for the food known as a conditioned flavor aversion (CFA). To determine if the low palatability of mesquite was due, at least in part, to a CFA we offered lambs a novel food and then infused mesquite into their rumens. We later examined consumption of the novel food for evidence of a CFA.

Adjustment Period. Twenty-one crossbred fine-wool lambs (1 year old) were each placed in an individual pen (1.5 x 2 $\mathrm{m})$ and fed a basal ration of ground alfalfa hay; $2 \% \mathrm{BW}$ fed daily at 1100 hours. Lambs for this trial were those used in the digestion trial and 6 from related experiments with mesquite. Water and trace mineral salt were offered ad libitum. Novel foods were offered before the trial to familiarize the lambs with the frequent presentation of new foods. Novel foods $(300 \mathrm{~g})$ were offered for $15 \mathrm{~min}$ per day at 0900 hours. Novel foods were soybean meal, crimped barley, and oregano-flavored rice (1\% oregano) offered for 3,2 , and 1 day(s), respectively.

Experimental Period. Seven days after animals were penned and offered novel foods daily, lambs were offered $300 \mathrm{~g}$ of rye grain, a novel food, at 0900 hours.

Table 1. Crude protein (CP), in situ digestibility, neutral detergent fiber (NDF), acid detergent fiber (ADF), and gross energy (GE) for diets consisting of various proportions of mesquite leaves and alfalfa.

\begin{tabular}{lcccccc}
\hline \hline & \multicolumn{5}{c}{ Levels of mesquite (\%) } \\
\cline { 2 - 7 } Parameter & $0($ Control) & 5 & 10 & 15 & 20 & $100^{1}$ \\
\hline CP (\%) & $11.5^{\mathrm{a}} \pm 1.7$ & $12.9^{\mathrm{a}} \pm 0.7$ & $12.2^{\mathrm{a}} \pm 1.7$ & $13.5^{\mathrm{a}} \pm 1.7$ & $12.9^{\mathrm{a}} \pm 0.7$ & $12.2^{\mathrm{a}} \pm<.1$ \\
Digestibility & & & & & & \\
In Situ (\%) & $68.6^{\mathrm{a}} \pm 1.4$ & $67.6^{\mathrm{a}} \pm 2.5$ & $67.3^{\mathrm{a}} \pm 2.1$ & $68.4^{\mathrm{a}} \pm 2.3$ & $66.8^{\mathrm{a}} \pm 1.7$ & $59.6^{\mathrm{b}} \pm 1.0$ \\
NDF (\%) & $40.6^{\mathrm{a}} \pm 0.2$ & $33.4^{\mathrm{a}} \pm 0.2$ & $36.4^{\mathrm{a}} \pm 0.3$ & $35.4^{\mathrm{a}} \pm 0.7$ & $36.3^{\mathrm{a}} \pm 0.4$ & $40.2^{\mathrm{a}} \pm 0.1$ \\
ADF (\%) & $30.6^{\mathrm{a}} \pm 0.6$ & $23.9^{\mathrm{a}} \pm 0.4$ & $27.4^{\mathrm{a}} \pm 0.4$ & $25.7^{\mathrm{a}} \pm 0.1$ & $26.7^{\mathrm{a}} \pm 0.3$ & $28.4^{\mathrm{a}} \pm 0.3$ \\
GE (cal g & & & & & & \\
\end{tabular}

$=100 \%$ mesquite was a control determination and it was not offered to lambs.

Means \pm Standard Error of lab duplicate and triplicate samples therefore not representing true replicates.

Values in rows followed by the same superscript are not different $(\mathrm{P}>0.05)$ 


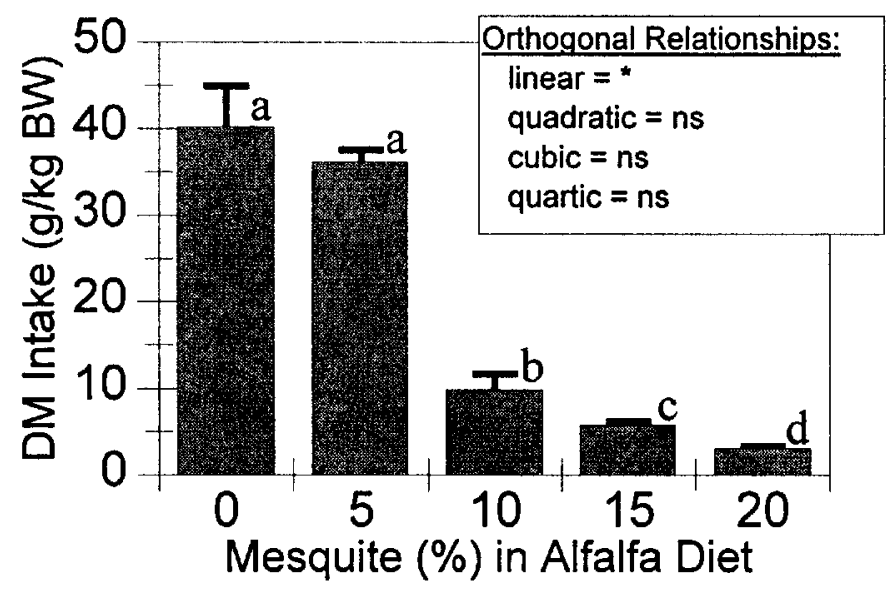

Fig. 1. Average daily dry matter (DM) intake of 4 levels of mesquite mixed with alfalfa hay by lambs. Vertical lines above bars illustrate standard errors, and bars with the same letter indicate no difference between treatments $(P>0.05)$. Orthogonal effects are designated as significant $(* ; P<0.05)$ or not significant $(\mathrm{ns} ; \mathrm{P}>0.05)$.

(Solbrig et al. 1977). Thus, "protein" may be a misleading term in this case. The proportion of mesquite in the treatment diets (0 to $20 \%$ ) did not affect in situ digestibility. However, a t-test comparing DM digestibility of alfalfa hay $(0 \%$ mesquite $)$ and mesquite leaves (100\% mesquite) revealed a higher digestibility of alfalfa hay. Fiber analysis revealed no clear trend or effect of increasing proportions of dietary mesquite on NDF or ADF. The variability in these parameters indicates high heterogeneity in the diet samples or imprecise application of lab protocols for measuring NDF and ADF. Gross energy was positively related to increasing amounts of mesquite in treatment diets. The $100 \%$ mesquite sample had clearly more energy $\left(\mathrm{cal} \mathrm{g}^{-1}\right)$ than the alfalfa con-

\section{trol (Table 1).}

Voluntary Intake. Mesquite leaves added to an alfalfa diet had a marked negative effect on DM intake (Fig. 1). Lambs offered a $5 \%$ mesquite diet had the same intake as lambs eating pure alfalfa. However, animals that were offered diets with $10 \%$ mesquite or more showed markedly lower intake than controls (Fig. 1). We attributed the low intake of diets containing more than $5 \%$ mesquite to the effect of plant allelochemicals. The voluntary intake of chemically defended plants by herbivorous mammals is hypothetically dependent on their detoxification capacity (Freeland 1991, Foley et al. 1995), thus the level of mesquite in the diet may have set an upper limit to total daily intake. If the intake of mesquite-containing diets

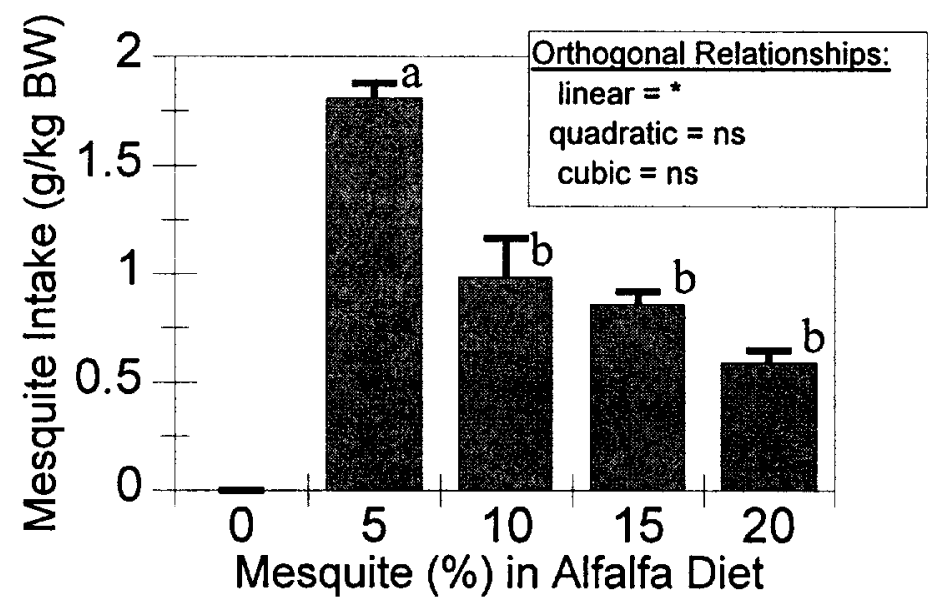

Fig. 2. Average daily dry matter (DM) intake of mesquite in diets with 4 levels of mesquite mixed with alfalfa hay by lambs. Vertical lines above bars illustrate standard errors, and bars with the same letter indicate no difference between treatments $(P>0.05)$. Orthogonal effects are designated as significant $(* ; P<0.05)$ or not significant $(\mathrm{ns} ; \mathrm{P}>0.05)$. was set by the maximum amount of mesquite a lamb could detoxify in a day, then the total daily intake of mesquite should be the same for all sheep, regardless of the proportion of mesquite in their diets. This was not the case. Lambs offered diets of 10,15 , and $20 \%$ mesquite ate an average of $0.78 \mathrm{~g} \mathrm{~kg}^{-1} \mathrm{BW}$ of mesquite daily. Lambs offered diets with $5 \%$ mesquite, ate more mesquite averaging $1.81 \mathrm{~g} \mathrm{~kg}^{-1} \mathrm{BW}$ (Fig. 2). Lambs may have been more able to detoxify and digest the dietary mesquite at the 5\% level because they had greater energy and nutrient intake from the greater proportion of alfalfa in their diets. This is speculative, however, abundant nutrient and energy resources can enhance an animal's ability to detoxify allelochemicals in plants (Foley et al. 1995, Launchbaugh 1996).

Changes in Live Weight. Low intake of diets with more than $5 \%$ mesquite resulted in weight loss for lambs assigned to those treatments. Lambs offered diets with 10 , 15 , and $20 \%$ mesquite lost 4.5, 5.0, and $6.2 \mathrm{~kg}$, respectively, during the trial with no difference between treatments. Weight loss in this short 17-day trial may be primarily attributed to loss of digestive tract fill. Diets with $0 \%$ and $5 \%$ mesquite resulted in 0.1 and $0.8 \mathrm{~kg}$ weight gain, respectively, during the trial with no difference between levels.

Apparent Digestibility. The proportion of mesquite in the diet did not affect DM digestibility (Fig. 3). The major effect of adding mesquite to the diet was depression of intake (Fig. 1). Although decreased intake often results in higher digestibility of foods (Van Soest 1994), no differences in digestibility were found when DM intake was accounted for as a covariate in this analysis. Similarly, no effect of mesquite on digestibility was observed in the assessment of in situ DM digestibility (Table 1). The in situ technique did yield comparatively higher digestibility than the in vivo method (Fig. 3 and Table 1). This difference may have resulted from differences in fermentation time. In vitro studies were conducted with 48 hours of fermentation whereas, in vivo digestion trials yielded an undetermined rumen residence time which may have been shorter than 48 hours.

Nitrogen Balance. Nitrogen retention was greatly reduced for animals offered diets with $>5 \%$ mesquite (Table 2). Retained $\mathrm{N}$ for lambs eating diets of $0 \%$ and $5 \%$ mesquite was very low but similar, indicating dietary protein levels close to maintenance requirements. When retained $\mathrm{N}$ was expressed as a percent of $\mathrm{N}$ intake, lambs eating diets with 0 or $5 \%$ 


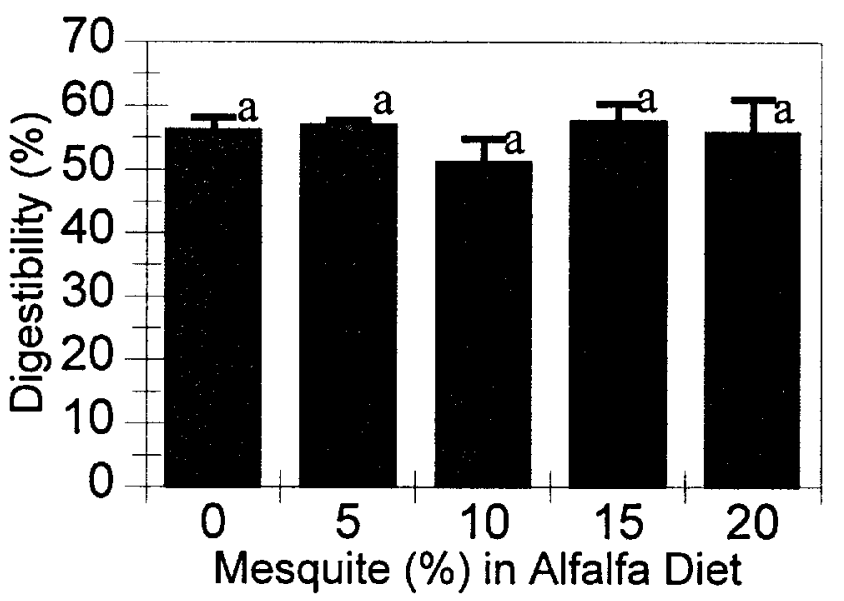

Fig. 3. Average coefficients of digestibility of 4 levels of mesquite added to alfalfa hay diets and eaten by lambs in a digestion trial. Vertical lines above bars illustrate standard errors.

mesquite had similar and positive retained $\mathrm{N}$ whereas lambs eating diets with $>5 \%$ mesquite were in a negative $\mathrm{N}$ balance. Total $\mathrm{N}$ output was similar for lambs eating diets of $0 \%$ and $5 \%$ mesquite, but markedly higher than for lambs offered diets with more than $5 \%$ mesquite. Nitrogen output in urine, as a percentage of total $\mathrm{N}$ output, was highest for levels of dietary mesquite $>5 \%$ (Table 2 ) suggesting catabolism of body protein to obtain energy for basal metabolism (Maynard et al. 1979).
Digestible Energy. Total intake of GE was negatively related to the mesquite level in the diet (Table 3). GE intake was similar for lambs eating diets with $0 \%$ and $5 \%$ mesquite, but began to decrease sharply when $10 \%$ or more mesquite was added to the diet. Mesquite in treatment gy intake per day. However, when DE was expressed as a $\%$ of intake, there was no difference between treatments. This indicates that GE was equally digestible in all diets. Total output of GE was also affected diets also strongly affected digestible ener- by dietary mesquite levels. Although, lambs assigned to $0 \%$ and $5 \%$ dietary mesquite showed no significant differences in GE output. Gross energy output of animals assigned to levels of mesquite greater than $5 \%$ differed from one another with animals eating diets with $20 \%$ mesquite having the lowest GE output (Table 3).

\section{Conditioned Flavor Aversion (CFA) Trial}

On the day animals were dosed with mesquite (Day 0), all lambs ingested similar amounts of the novel feed, rye (Table 4 ). The animals were then dosed with mesquite within 30 minutes of rye consumption. The following day (Day 1), the consumption of the familiar food, barley, was not affected by the dose of infused mesquite. Therefore, if mesquite dosing caused gastro-intestinal malaise, it was not apparent 24 hours after dosing.

Mesquite dosing after rye consumption created a strong CFA to rye. On Day 2, lambs receiving either levels of mesquite infusion ate less rye than the control group (Table 4). There were no differences in the amount of rye eaten between lambs dosed with 3.0 or $4.5 \mathrm{~g}$ of mesquite $\mathrm{kg}^{-1} \mathrm{BW}$. On the same day, intake of a familiar feed, rice, immediately after consumption of rye, was similar among the 3 groups of

Table 2. Daily nitrogen balance of lambs fed diets with 5 levels of mesquite leaves in an alfalfa hay diet. Values were adjusted to the weight of an average lamb $(28.1 \mathrm{~kg})$ in this trial.

\begin{tabular}{|c|c|c|c|c|c|c|c|c|c|}
\hline \multirow{3}{*}{ Treatments } & \multicolumn{7}{|c|}{ Nitrogen } & \multirow{2}{*}{\multicolumn{2}{|c|}{ Urinary }} \\
\hline & Intake $^{1}$ & \multicolumn{2}{|c|}{ Retained } & \multicolumn{2}{|c|}{ Total Output } & \multicolumn{2}{|c|}{ Fecal } & & \\
\hline & (g) & (g) & (\% Intake) & (g) & (\% Intake) & (g) & (\% Output) & (g) & (\% Output) \\
\hline Control & $21.0 \pm 3.1^{\mathrm{a}}$ & $1.3 \pm 1.6^{\mathrm{a}}$ & $6.2^{\mathrm{a}}$ & $19.7 \pm 2.6^{\mathrm{a}}$ & 93.8 & $6.9 \pm 1.6$ & $35.0^{\mathrm{a}}$ & $12.9 \pm 1.6$ & $65.5^{\mathrm{a}}$ \\
\hline 10 & $5.5 \pm 1.2^{\mathrm{b}}$ & $-2.5 \pm 0.7^{\mathrm{ab}}$ & $-45.5^{\mathrm{b}}$ & $8.0 \pm 1.2^{\mathrm{b}}$ & 145.5 & $2.1 \pm 0.3$ & $26.2^{\mathrm{bc}}$ & $5.9 \pm 0.8$ & $73.8^{\mathrm{bc}}$ \\
\hline 15 & $3.5 \pm 0.3^{\mathrm{b}}$ & $-1.6 \pm 0.1^{\mathrm{b}}$ & $-45.7^{\mathrm{b}}$ & $5.1 \pm 0.4^{\mathrm{bc}}$ & 145.7 & $1.0 \pm 0.1$ & $19.6^{\mathrm{c}}$ & $4.1 \pm 0.2$ & $80.4^{\mathrm{c}}$ \\
\hline 20 & $1.7 \pm 0.2^{\mathrm{c}}$ & $-0.8 \pm 0.2^{\mathrm{c}}$ & $-47.1^{\mathrm{b}}$ & $2.5 \pm 0.4^{\mathrm{c}}$ & 147.1 & $0.6 \pm 0.0$ & $24.0^{\mathrm{bc}}$ & $1.9 \pm 0.3$ & $76.0^{\mathrm{bc}}$ \\
\hline
\end{tabular}

Means \pm Standard Errors

Values in columns followed by the same superscript are not different $(\mathrm{P}>0.05)$

1 = Natural $\log (\mathrm{x})$ transformed for homoscedasticity

$2=1 / x$ values transformed for homoscedasticity

Table 3. Effects of 5 levels of mesquite leaves in alfalfa hay diets on gross energy (GE) intake, digestible energy, and energy output. Data from in vivo digestion trial with lambs. Values were adjusted for an average animal $(28.1 \mathrm{~kg})$ in this trial.

\begin{tabular}{|c|c|c|c|c|c|c|c|c|c|}
\hline \multirow[t]{2}{*}{ Treatments } & \multirow{2}{*}{$\begin{array}{c}\mathrm{GE} \\
\text { Intake } \\
\text { (Kcal) }\end{array}$} & \multicolumn{2}{|c|}{$\begin{array}{c}\text { Digestible } \\
\text { Energy }\end{array}$} & \multicolumn{2}{|c|}{$\begin{array}{c}\text { Total } \\
\text { GE Output }\end{array}$} & \multicolumn{2}{|c|}{$\begin{array}{c}\text { Fecal } \\
\text { GE Output }\end{array}$} & \multicolumn{2}{|c|}{$\begin{array}{c}\text { Urinary } \\
\text { GE Output }\end{array}$} \\
\hline & & (Kcal) & $(\%)$ & (Kcal) & (\% Intake) & (Kcal) & (\% Output) & (Kcal) & (\% Output) \\
\hline Control & $4662 \pm 679^{a}$ & $2431 \pm 216^{\mathrm{a}}$ & $52.1^{\mathrm{a}}$ & $2396^{\mathrm{a}} \pm 426$ & 51.4 & $2231 \pm 418$ & $93.1^{\mathrm{a}}$ & $165 \pm 21$ & $6.9^{\mathrm{a}}$ \\
\hline 5 & $4191 \pm 194^{a}$ & $2229 \pm 113^{\mathrm{a}}$ & $53.2^{\mathrm{a}}$ & $2122^{a} \pm 68$ & 50.6 & $1963 \pm 56$ & $92.5^{\mathrm{a}}$ & $59 \pm 12$ & $7.5^{\mathrm{a}}$ \\
\hline 10 & $1146 \pm 25^{\mathrm{b}}$ & $542 \pm 130^{\mathrm{b}}$ & $47.3^{\mathrm{a}}$ & $666^{b} \pm 108$ & 58.1 & $603 \pm 102$ & $90.5^{\mathrm{a}}$ & $63 \pm 6$ & $9.5^{\mathrm{a}}$ \\
\hline 15 & $676 \pm 58^{\mathrm{c}}$ & $362 \pm 4^{b}$ & $53.6^{\mathrm{a}}$ & $358^{\mathrm{c}} \pm 56$ & 53.0 & $314 \pm 55$ & $87.7^{b}$ & $44 \pm 3$ & $12.3^{b}$ \\
\hline 20 & $359 \pm 42^{\mathrm{d}}$ & $169 \pm 25^{\mathrm{c}}$ & $52.8^{\mathrm{a}}$ & $203^{d} \pm 28$ & 56.5 & $169 \pm 25$ & $83.3^{c}$ & $33 \pm 4$ & $16.7^{\mathrm{c}}$ \\
\hline
\end{tabular}

Means \pm standard errors

Values in columns followed by the same superscript are not different $(\mathrm{P}>0.05)$ 
Table 4. Mean intake of novel food (rye), and familiar food (rice) by lambs before and after intraruminal dosing with ground mesquite.

\begin{tabular}{|c|c|c|c|c|c|c|c|c|}
\hline \multirow{3}{*}{$\begin{array}{l}\text { Mesquite } \\
\text { Dose } \\
\text { g/kg BW }\end{array}$} & \multirow{2}{*}{\multicolumn{2}{|c|}{$\begin{array}{c}\text { Before dosing } \\
\text { Day } 0 \\
\end{array}$}} & \multicolumn{6}{|c|}{ After dosing } \\
\hline & & & \multicolumn{2}{|c|}{ Day 2} & \multicolumn{2}{|c|}{ Day 2} & \multicolumn{2}{|c|}{ Day 3} \\
\hline & Rye & $\%^{1}$ & Rye & $\%^{2}$ & Rice & $\%^{2}$ & Rye & $\%^{1}$ \\
\hline 0 & $9+25$ & 87 & & 84 & $\mathrm{a}^{\mathrm{a}}$ & 100 & $a^{\mathrm{a}}$ & 98 \\
\hline 3 & $260.3 \pm 19.8^{\mathrm{a}}$ & 87 & $22.4 \pm 21.4^{\mathrm{b}}$ & 9 & $171.7 \pm 28.3^{\mathrm{a}}$ & 86 & $52.7 \pm 49.1^{\mathrm{b}}$ & 18 \\
\hline 4.5 & $277.6 \pm 14.5^{\mathrm{a}}$ & 93 & $52.1 \pm 35.3^{\mathrm{b}}$ & 21 & $135.9 \pm 33.8^{\mathrm{a}}$ & 68 & $109.2 \pm 60.6^{\mathrm{b}}$ & 36 \\
\hline
\end{tabular}

$\%$ of total offered ( $300 \mathrm{~g}$ ) before dosing and on third day after dosing

${ }^{2} \%$ of total offered rye $(250 \mathrm{~g})$ and rice $(200 \mathrm{~g})$ after dosing

Means in columns followed by the same letter are not different

lambs. Thus, the low rye intake by lambs dosed with mesquite was not because of a general loss of appetite for all grains; but rather, a specific aversion to rye. On Day 3 , intake of rye by lambs receiving either the low or high mesquite dose was higher than on Day 2 increasing by 52.7 and $109.2 \mathrm{~g}$, respectively. This increased intake probably indicates initial extinction of the aversion to rye.

Alfalfa Intake. Intake of the alfalfa basal ration before and for 3 days after dosing showed a variable pattern with some animals apparently less affected by the mesquite dosing than others. After dosing, lambs receiving the highest dose of mesquite ate less alfalfa than lambs receiving the control or low mesquite dose (Table 5). After 2 days, lambs receiving the high dose of mesquite increased their average intake of alfalfa slightly (from 8.6 to $12.1 \mathrm{~kg}^{-1} \mathrm{BW}$; Table 5), but still ate less than other lambs. This may be explained by an aversion to the familiar alfalfa ration (Burritt and Provenza 1991). Alfalfa was fed 90 min after dosing and the negative post-ingestive feedback caused by mesquite may have created an aversion to chopped alfalfa. Alternatively, the lower consumption of the chopped alfalfa hay may reflect a general loss of appetite. Lambs infused with the highest mesquite dose showed symptoms of gastro-intestinal distress. Only 2 lambs receiving the low dose showed symptoms of diarrhea and they recovered completely by the last day of the trial, while, 4 (out of 6) lambs receiving the highest mesquite dose, showed symptoms of diarrhea that lasted until the last day of the trial. Allelochemicals in mesquite may have caused diarrhea through effects on gastrointestinal motility, fore-stomach disorders, or osmotic overload (Smith 1990).

\section{Conclusions and Management Implications}

Mesquite leaves added at increasing proportions to alfalfa hay did not change basic composition (CP, GE, in situ digestibility, ADF or NDF) of the diet as measured by laboratory methods. Likewise, no differences in the in vivo DM digestibility of mesquite containing diets were found. The main effect of increasing levels of mesquite in experimental diets was reduced intake. In the digestion trial, lambs offered diets with $5 \%$ mesquite had similar intake and weight gain as lambs offered $100 \%$ alfalfa diets. This observed maximum consumption around $5 \%$ of the diet agrees with studies of wild and domestic animals in range conditions that seldom report more than $5 \%$ dietary mesquite (Warren et al. 1984, Krausman et al. 1997).

The strong negative effect of mesquite on intake in this study indicates that one or several allelochemicals in mesquite act as powerful feeding deterrents. The formation of a CFA to a novel food after ruminal infusion of mesquite in our second trial was evidence of negative post-ingestive feedback from mesquite leaves. The palatability of mesquite is certainly influenced by post-ingestive feedback although an inherently aversive taste may also play a role (Provenza et al. 1990, Launchbaugh 1996). Intake of the alfalfa basal ration was also affected by mesquite dosing.

Table 5. Mean intake ( \pm standard error) of alfalfa hay ration by lambs before and after intra-ruminal dosing with ground mesquite leaves.

\begin{tabular}{|c|c|c|c|c|}
\hline \multirow{2}{*}{$\begin{array}{l}\text { Mesquite } \\
\text { Dose } \\
\mathrm{g} / \mathrm{kg} \mathrm{BW}\end{array}$} & \multirow{2}{*}{$\frac{\text { Before }}{\text { Day } 0}$} & \multicolumn{3}{|c|}{ After } \\
\hline & & Day 1 & Day 2 & Day 3 \\
\hline \multicolumn{5}{|c|}{$\ldots \ldots \ldots-\ldots, \mathrm{g} \mathrm{kg}^{-1}$ of body weight $) \cdots \cdots \cdots$} \\
\hline 0 & $20.1 \pm 1.0 \mathrm{a}$ & $20.1 \pm 1.0 \mathrm{a}$ & $20.1 \pm 1.0 \mathrm{a}$ & $20.1 \pm 1.0 \mathrm{a}$ \\
\hline 3 & $20.4 \pm 0.4 \mathrm{a}$ & $20.2 \pm 0.5 a$ & $17.4 \pm 1.5 \mathrm{a}$ & $20.4 \pm 0.4 a$ \\
\hline 4.5 & $17.9 \pm 3.1 \mathrm{a}$ & $15.2 \pm 2.8 \mathrm{a}$ & $8.6 \pm 1.8 \mathrm{~b}$ & $12.1 \pm 2.8 b$ \\
\hline
\end{tabular}

Means followed by the same superscripts in columns are not different $(\mathrm{P}>0.05)$
Animals that received the highest mesquite dose reduced their intake of the familiar alfalfa diet and showed symptoms of diarrhea for at least three days.

Allelochemicals are known to limit the nutritive value of many plants and can have various biological effects, such as interfering with metabolism or inhibiting digestion (Provenza 1995, Launchbaugh 1996). The main groups of allelochemicals identified in honey mesquite leaves are flavonoids and non-protein amino acids which may have antiquality properties (Solbrig et al. 1977). Allelochemicals identified in other mesquite species include phenolics (Lyon et al. 1988) and alkaloids (Cates and Rhoades 1977). The animal response in our experiments agrees with a general feeding strategy of herbivores to minimize the ingestion of defensive compounds (Freeland 1991).

This research suggests that grazing management practices could be designed to rely on mesquite leaves for about $5 \%$ of the grazing animal's dry matter requirements. It is unlikely that mesquite could constitute a large $(>10 \%)$ proportion of forage allowance on rangeland. However, mesquite may be an important source of nitrogen and vitamin $\mathrm{A}$ in late summer because it continues active growth after herbaceous forage becomes senescent.

Increased consumption of mesquite as part of mesquite management plans could be accomplished by selecting animals with enhanced detoxification or tolerance for mesquite. In our trials and in other studies (Warren et al. 1984), there was considerable variation between individuals with respect to voluntary mesquite consumption. Assembling herds or flocks of animals with enhanced detoxification or tolerance abilities could constitute a management strategy to increase the use of mesquite as forage on rangeland. Breeding animals for high mesquite consumption could also be used as a management tool if the metabolic basis for mesquite tolerance or detoxification is inherited. Finally, research is needed to identify the specific chemicals that make mesquite unpalatable and the mechanisms by which these chem- 
icals affect herbivores. Understanding these chemical effects could lead to pharmaceutical or nutritional products that aid in detoxification or tolerance. These elements may one day become part of viable grazing management strategies for mesquite-dominated rangelands.

\section{Literature Cited}

AOAC. 1984. Official methods of analysis. (14th Ed). Assoc. of Official Analytical Chem., Washington, D.C.

Burrit, E.A. and F.D. Provenza. 1991. Ability of lambs to learn with a delay between food ingestion and consequences given meals containing novel and familiar foods. Appl. Anim. Behav. Sci. 32:179-189.

Cates, R.G.and D.F. Rhoades. 1977. Prosopis leaves as a resource for insects, p. 61-83. In: B.B. Simpson (ed.), Mesquite: Its biology in two desert ecosystems. Dowden, Hutchinson $\&$ Ross, Inc., Stroudsburg, Penn.

Dahl, B.E. 1982. Mesquite as a rangeland plant. p. A1-A20. In: H.W.Parker (ed.) Mesquite utilization. Symposium on Mesquite Utilization. Texas Tech Univ. Press, Lubbock, Tex.

Dahl, B.E. and R.E. Sosebee. 1984. Timing the key to herbicidal control of mesquite. Texas Tech. Univ. Manage. Note. N 2.

Deinum, B. and A. Maassen. 1994. Effects of drying temperature on chemical composition and in vitro digestibility of forages. Animal Feed Sci. and Tech. 46:74-86.

Fisher, C.E. 1977. Mesquite and modern man in southwestern North America. p. 177-188. In: B.B. Simpson (ed.) Mesquite: Its biology in two desert ecosystems. Dowden, Hutchinson \& Ross, Inc., Stroudsburg, Penn.

Foley, W.J., S. McLean and S.J. Cork. 1995. Consequences of biotransformation of plant secondary metabolites on acid-base metabolism in mammals: A final common pathway? J. Chem. Ecol. 21:721-743.

Freeland, W.J. 1991. Plant secondary metabolites. Biochemical coevolution with herbivores. p. 61-81. In: R.T. Palo, and C.T. Robbins (eds.), Plant defenses against mammalian herbivory. CRC Press, Inc., Boca Raton, Fla.

Harris, L.E. 1970. Nutrition research techniques for domestic and wild animals. Vol.1. Utah State Univ. Logan, Ut.

Harris L.E., G.P. Lofgreen, C.J. Kercher, R.J. Raleigh and V.R. Bohman. 1967. Techniques of research in range livestock nutrition. Utah Agr. Exp. Sta. Bull. 471. Logan, Ut.

Holechek, J.L. and K. Hess. 1994. Brush control considerations: A financial perspective. Rangelands 14:279-284.

Komarek, A.R., J.B. Robertson, and P.J. Van Soest. 1994. A comparison of methods for determining $\mathrm{ADF}$ using the filter bag technique versus conventional filtration. J. Dairy Sc. 77: Suppl. 1.
Krausman, P.R., A.J. Kuenzi, R.C. Etchberger, K.R. Rautenstrauch, L.L. Ordway, and J.J. Herbert. 1997. Diets of desert mule deer. J. Range Manage. 50:513-522

Launchbaugh, K.L. 1996. Biochemical aspects of grazing behavior. p. 159-184. In: J. Hodgson, and A.W. Illius (eds.), The ecology and management of grazing systems. CAB International, Wallingford, U.K.

Lyon, C.K, M.R. Gumbmann, and R. Becker. 1988. Value of mesquite leaves as forage. J. Sci. Food. Agr. 44:111-117.

Maynard, L.A., J.K. Loosli, H.F. Hintz, R.G. Warner. 1979. Animal Nutrition. 7th Ed. McGraw-Hill Book Co.

Meyer, R.E., H.L. Morton, R.H. Haas, E.D. Robison, and T.E. Riley. 1971. Morphology and anatomy of honey mesquite. Agr. Res. Serv. USDA. Tech. Bull. 1423.

Paladines, O.L., J.T. Reid, B.D.H. Van Niekerk, and A. Bensadoun. 1963. Relationship between the nitrogen content and the heat of combustion value of sheep urine. J. Anim. Sci. 23:528-532.

Pritz, R.K., K.L. Launchbaugh, and C.A. Taylor, Jr. 1997. Effects of breed and dietary experience on juniper consumption by goats. J. Range Manage. 50:600-606.

Provenza, F.D. 1995. Postingestive feedback as an elementary determinant of food preference and intake in ruminants. J. Range Manage. 48:2-17.

Provenza, F.D. , J.A. Pfister, and C.D. Cheney. 1992. Mechanisms of learning in diet selection with reference to phytotoxicosis in herbivores. J. Range Manage. 45:36-45.

Provenza, F.D. , E.A. Burrit, T.P. Clausen, J.P. Bryant, P.B. Reichardt, and R.A. Distel. 1990. Conditioned flavor aversion: a mechanism for goats to void condensed tannins in blackbrush. Amer. Nat., 136:810-828.

SAS. 1996. Statistical analysis system. Ver. 6.09. SAS Institute Inc. Cary, N.C.

Schneider, B.H. and W.P. Flatt. 1975. The evaluation of feeds through digestibility experiments. Univ. of Georgia Press, Athens. Ga.

Smith, B.P. 1990. Alternations in alimintary and hepatic function. P. 117-124. In: B.P. Smith (ed). Large Animal Intestinal Medicine. CV Mosby Comp. St. Louis, Mo.

Solbrig, O.T., K. Bawa, N.J. Carman, J.H. Hunziker, C.A. Naranjo, R.A. Palacios, L. Poggio, and B.B. Simpson. 1977. p. 44-60. Patterns of variation. In: B.B. Simpson (ed). Mesquite: Its biology in two desert ecosystems. Dowden, Hutchinson \& Ross, Inc. Stroudsburg, Penn.

Steel, R.G.D. and J.H. Torrie. 1980. Principles and procedures of statistics. 2nd Ed. McGraw-Hill Book Company, Inc., N.Y.

SYSTAT. 1992. Systat for windows: Statistics. Version 5 Ed. Evanston, Ill.

Van Dyne, G.M. and W.C. Weir. 1964. Variation among cattle and sheep in digestive power measured by microdigestion techniques. J. Animal. Sci. 23:1116-1123.
Van Soest, P.J. 1994. Nutritional ecology of the ruminant. Cornell University Press, Ithaca, N.Y.

Van Soest, P.J., J.B. Robertson, and B.A. Lewis. 1991. Methods for dietary fiber, neutral detergent fiber and non-starch polysaccharides in relation to animal nutrition. J. Dairy Sci. 74:3583-3597.

Warren, L.E., D.N. Ueckert, and J.M. Shelton. 1984. Comparative diets of Rambouillet, Barbado, and Karrakul sheep and Spanish and Angora goats. J. Range Manage. 37:172-180.

Wolf, D.D. and E.W. Carson. 1973. Respiration during drying of alfalfa herbage. Crop. Sci. 13:660-662.

Zolfaghari, R., M. Harden and L. Hopkins. 1982. Nutritional value of mesquite beans $(P$. glandulosa). p. K1-K12. In: H.W.Parker (ed.) Mesquite utilization. Symposium on mesquite utilization. Texas Tech Univ. Press, Lubbock, Tex. 